\title{
Adjuvant chemotherapy for gastric cancer: a comprehensive review
}

\author{
Yoshiniko Maehara ${ }^{1}$, Hideo Baba ${ }^{2}$, and Keizo Sugimachi ${ }^{1}$ \\ ${ }^{1}$ Department of Surgery and Science, Graduate School of Medical Sciences, Kyushu University, 3-1-1 Maidashi, Higashi-ku, \\ Fukuoka 812-8582, Japan \\ ${ }^{2}$ Department of Surgery, National Kyushu Cancer Center, Fukuoka, Japan
}

\begin{abstract}
The role of adjuvant chemotherapy in gastric cancer has been studied extensively over the past three decades in an attempt to further improve the prognosis of patients with gastric cancer who have undergone curative surgery. To date, no definitive conclusions have been drawn from randomized clinical trials of adjuvant chemotherapy for gastric cancer, because few studies have shown a significant positive impact on survival as compared with surgery alone. The negative results of most previous clinical studies do not necessarily mean that the adjuvant chemotherapy approach to treatment of gastric cancer does not work. Recent published reports of meta-analyses concerning adjuvant chemotherapy of gastric cancer revealed small but clear survival advantages for adjuvant therapy over surgery alone. The positive data from meta-analyses suggests that there are potential survival advantages of adjuvant chemotherapy, but this must be proven in the future by welldesigned clinical trials that compare adjuvant chemotherapy with surgery alone, in which sufficient numbers of patients are enrolled and effective chemotherapeutic regimens with appropriate dose intensity are employed. Newly developed anticancer agents and/or newer therapeutic combinations or strategies (neoadjuvant chemotherapy, chemoradiotherapy, intraperitoneal chemotherapy) have the potential to benefit high-risk patients.
\end{abstract}

Key words Adjuvant chemotherapy - Gastric cancer . Chemoimmunotherapy

\section{Introduction}

A gradual increase in overall survival after curative surgery for advanced gastric cancer has recently been reported [1]. Even after curative surgery, however, especially in the advanced stages of gastric cancer, re-

Offprint requests to: Y. Maehara

Received: June 6, 2001 / Accepted: August 24, 2001 currences are often experienced [2], as a result of which tremendous efforts have been made over the past three decades to further improve the clinical outcomes of gastric cancer with postoperative adjuvant chemotherapy, both in Japan and Western countries [3]. To date, worldwide, no definitive conclusions concerning the efficacy of adjuvant chemotherapy for gastric cancer have been reached. A few reports from Western countries support the survival benefits of adjuvant chemotherapy for gastric cancer, whereas Japanese reports suggest favorable results in limited subsets of patients treated $[3,4]$. These differences may stem from several differences between Japan and Western countries in the methodologies employed in clinical trials as an adjuvant setting. Many factors may interfere with the interpretation of the data, as follows [5,6]. (1) The details of surgery and pathology for curative resection of advanced gastric cancer seem to differ. While most Japanese surgeons perform quite a uniform extended lymph node dissection (D2 or D3) and radical gastrectomy with a sufficiently free margin from the tumor, many patients in Western countries undergo less than the recommended (D1) lymph node dissection [7]. Thus, the residual tumor burden seems to differ, even in potentially curative cases, between Japan and Western countries. Furthermore, pathological evaluation of the dissected lymph nodes is often inadequate in Western countries. (2) Worldwide, the staging systems employed have been different, such that comparisons of survival results of surgery with or without adjuvant chemotherapy in the past have been confused [5]. Moreover, because the staging systems for gastric cancer have changed a number of times over the decades, it has often been difficult to establish exactly which staging system was involved. (3) Previous Japanese clinical trials for adjuvant chemotherapy enrolled patients at all stages of the disease, had inadequate sample sizes, and often lacked surgery alone as a control arm [8]. (4) The initiation of postoperative chemotherapy varies widely 
[9]. In Japan, postoperative treatment for gastric cancer patients begins immediately after surgery, whereas in Western countries, treatment often starts 4 to 6 weeks after surgery, and this factor may have an influence on the efficacy of adjuvant chemotherapy. (5) Chemotherapy regimens and the dose intensity employed vary between centers and countries. Most Japanese adjuvant chemotherapy regimens include mitomycin C (MMC) with an oral 5-fluorouracil (5-FU) analogue, while Western countries have been using nitrosurea-, MMC-, and doxorubicin-containing regimens in combination with intravenous 5-FU [3,4].

As mentioned above, there have been several differences in the methodologies of adjuvant chemotherapy between Japan and Western countries. Thus, for this article, we have reviewed reports of adjuvant chemotherapy for gastric cancer from Japan and Western countries separately.

\section{Japanese postoperative adjuvant chemotherapy trials}

\section{Adjuvant chemotherapy vs surgery alone}

In Japan, the National Hospital Cooperative Cancer Chemotherapy Study Group conducted multi-center clinical trials of postoperative adjuvant chemotherapy for gastric cancer from 1959 to 1978 [10,11]. In eight trials, several regimens containing MMC, Triethylene Thiophosphoramide (thio-TEPA), or MMC combined with 5-FU were tested, but no significant survival advantages were found over surgery alone. Table 1 lists studies of postoperative adjuvant chemotherapy comparing the treatment arm to a surgery-alone arm [1220]. Adjuvant MMC has been used as a moderate dose delivery medium over the long term $(0.08 \mathrm{mg} / \mathrm{kg}$, twice a week for 5 weeks) $[12,13]$. There was no prolongation in overall survival, but significant benefits were seen in stages II or III by subset analysis. The combination of the three drugs, MMC, 5-FU, and cytosine arabinoside (MFC) produced a favorable result [14]. Although there was no significant survival difference among all patients tested, MFC therapy revealed a significant survival benefit in the subset of stages II and III patients. Based on the previous results, Nakajima et al. [16] conducted a subsequent clinical trial in which patients with curative surgery were randomized to receive either MFC plus oral 5-FU, MFC plus tegafur (FT), or surgery alone. Although they did not achieve a significant survival benefit in the treated group, there was a $17 \%$ difference in the 5-year survival rates between the MFC + FT and control groups. The MFC + FT regimen was superior to

Table 1. Adjuvant chemotherapy for gastric cancer: Japanese studies (chemotherapy vs surgery alone [control])

\begin{tabular}{|c|c|c|c|c|c|}
\hline $\begin{array}{l}\text { Author } \\
\text { (year) }\end{array}$ & $\begin{array}{l}\text { No. of } \\
\text { patients }\end{array}$ & Treatment & Percent survival/years & $P$ value & $\begin{array}{l}\text { Suggested } \\
\text { data }\end{array}$ \\
\hline $\begin{array}{l}\text { Imanage }[12] \\
\quad(1977)\end{array}$ & $\begin{array}{l}242 \\
283\end{array}$ & $\begin{array}{l}\text { A: MMC } \\
\text { B: Control }\end{array}$ & $\begin{array}{l}68 / 5 \\
54 / 5\end{array}$ & NS & $\begin{array}{l}\text { Stage II, III } \\
\quad \mathrm{A}>\mathrm{B}\end{array}$ \\
\hline $\begin{array}{l}\text { Nakajima }[13] \\
\quad(1978)\end{array}$ & $\begin{array}{l}207 \\
223\end{array}$ & $\begin{array}{l}\text { A: MMC } \\
\text { B: Control }\end{array}$ & $\begin{array}{l}52 / 5 \\
44 / 5\end{array}$ & NS & $\begin{array}{l}\text { Stage III } \\
\quad \mathrm{A}>\mathrm{B}\end{array}$ \\
\hline $\begin{array}{l}\text { Nakajima [14] } \\
\quad(1980)\end{array}$ & $\begin{array}{l}42 \\
40 \\
38\end{array}$ & $\begin{array}{l}\text { A: MMC } \\
\text { B: MMC/5-FU/Ara C } \\
\text { C: Control }\end{array}$ & $\begin{array}{l}64.3 / 5 \\
66.9 / 5 \\
56.0 / 5\end{array}$ & $\begin{array}{l}\text { NS } \\
0.05\end{array}$ & $\mathrm{~S}+\mathrm{B}>\mathrm{C}$ \\
\hline $\begin{array}{l}\text { Ochiai [15] } \\
\text { (1983) }\end{array}$ & $\begin{array}{l}49 \\
49 \\
40\end{array}$ & $\begin{array}{l}\text { A: MMC/5-FU/Ara C + FT } \\
\text { B: MMC/5-FU/Ara C + FT + BCG } \\
\text { C: Control }\end{array}$ & $\begin{array}{l}36 / 5 \\
18 / 5 \\
31 / 5\end{array}$ & 0.05 & \\
\hline $\begin{array}{l}\text { Nakajima [16] } \\
\text { (1984) }\end{array}$ & $\begin{array}{l}81 \\
83 \\
79\end{array}$ & $\begin{array}{l}\text { A: MMC/5-FU/Ara C + 5-FU } \\
\text { B: MMC/5-FU/Ara C + FT } \\
\text { C: Control }\end{array}$ & $\begin{array}{l}68.4 / 5 \\
62.5 / 5 \\
51.4 / 5\end{array}$ & NS & $\begin{array}{l}\text { Stage III } 56.1 \% \\
P<0.05 \\
5.3 \%\end{array}$ \\
\hline $\begin{array}{l}\text { Yamamura [17] } \\
(1986)\end{array}$ & $\begin{array}{l}32 \\
33 \\
34\end{array}$ & $\begin{array}{l}\text { A: MMC/5-FU } \\
\text { B: MMC/5-FU/OK-432 } \\
\text { C: Control }\end{array}$ & $\begin{array}{l}53.1 / 5 \\
66.7 / 5 \\
58.8 / 5\end{array}$ & NS & \\
\hline $\begin{array}{l}\text { Maehara [18] } \\
\quad(1990)\end{array}$ & $\begin{array}{l}137 \\
118\end{array}$ & $\begin{array}{l}\text { A: MMC/5-FU/PSK } \\
\text { B: Control }\end{array}$ & $\begin{array}{l}56.9 / 15 \\
45.7 / 15\end{array}$ & 0.03 & \\
\hline $\begin{array}{l}\text { Fujii [19] } \\
\text { (1994) }\end{array}$ & $\begin{array}{l}70 \\
72 \\
34\end{array}$ & $\begin{array}{l}\text { A: MMC/5-FU (6 months) } \\
\text { B: MMC/5-FU (12 months) } \\
\text { C: Control }\end{array}$ & $\begin{array}{l}51.5 / 5 \\
72.2 / 5 \\
56.1 / 5\end{array}$ & NS & \\
\hline $\begin{array}{l}\text { Nakajima [20] } \\
\text { (1999) }\end{array}$ & $\begin{array}{l}285 \\
288\end{array}$ & $\begin{array}{l}\text { A: MMC/5-FU + UFT } \\
\text { B: Control }\end{array}$ & $\begin{array}{l}82.9 / 5 \\
85.8 / 5\end{array}$ & NS & \\
\hline
\end{tabular}

NS, Not significant; MMC, Mitomycin C; 5-FU, 5-flnorouracil; Ara C, cytosine-arabinoside; FT, tegafur; BCG, Bacillus Calmette-Guerin; PSK, protein-bound polysaccharide; UFT, tegafur-uracil 
the control in the subsets of stages I to III patients. Ochiai et al. [15] found a significant survival advantage among patients treated postoperatively with $\mathrm{MFC}+\mathrm{FT}$ and Bacillus Calmette-Guerin (BCG) over surgery alone. We also found a significant survival improvement in patients treated with $\mathrm{MMC}+5 \mathrm{FU}$ combined with protein-bound polysaccharide (PSK), a potent immunomodulator, when compared with a surgery alone group [18]. More recently, Nakajima et al. [20] reported the results of a phase III clinical trial of adjuvant chemotherapy after curative gastrectomy for macroscopically serosa-negative gastric cancer. In their study, 579 patients were allocated randomly to adjuvant chemotherapy with MMC + UFT or no further treatment. Although there was no survival benefit with the adjuvant therapy for patients with macroscopically serosa-negative gastric cancer after curative surgery, subset analysis showed a better survival rate among the chemotherapy group in T2 patients $(83.0 \%$ vs $76.9 \%)$. They concluded that patients with $\mathrm{T} 1$ cancer could be excluded from future trials, because curative surgery alone yielded a very high survival rate, and there seemed to be no need for adjuvant therapy.

\section{Chemotherapy vs chemotherapy}

In Japan since the 1980s, most clinical trials of postoperative adjuvant chemotherapy for gastric cancer have consisted of chemotherapy treatment arms without a surgery alone control arm. As a result of early trials conducted in Japan in the 1970s, MMC with or without 5-FU is now regarded as a standard regimen for postoperative adjuvant chemotherapy, because subset analyses of trials often indicated superior survival curves for the treatment groups compared with surgery alone in stage II or III patients. Table 2 shows a summary of Japanese clinical trials of postoperative adjuvant chemotherapy without a surgery-alone control arm [21-28]. Inokuchi et al. [21] investigated the effect of MMC plus FT in comparison to MMC alone. There was no significant survival advantage in the MMC plus FT group. When subset analysis was conducted, however, patients with stage III disease who received a high dose of MMC survived longer than those who received a moderate dose of MMC $(P=0.036)$. Similarly, the combination of MMC plus FT was evaluated in a prospective randomized control trial by Hattori et al. [22]. A total of 2873 patients were randomized to MMC alone, FT alone, or MMC plus FT. There were no significant differences in the 5-year survival rates among the three treatment arms, except for subset analyses showing the superiority of the FT or MMC + FT groups over the MMC-only group in stage III. We compared the effect of MMC plus UFT, with MMC plus FT in patients with resected stage IV gastric cancer [24]. Although the number of patients was small, MMC + UFT had significant survival benefit, with a 5-year survival rate of $23 \%$, vs $13 \%$ for MMC

Table 2. Adjuvant chemotherapy for gastric cancer in Japan

\begin{tabular}{|c|c|c|c|c|c|}
\hline $\begin{array}{l}\text { Author } \\
\text { (year) }\end{array}$ & $\begin{array}{l}\text { No. of } \\
\text { patients }\end{array}$ & Treatment & Percent survival/years & $P$ value & $\begin{array}{l}\text { Suggested } \\
\text { data }\end{array}$ \\
\hline $\begin{array}{l}\text { Inokuchi [21] } \\
\quad(1984)\end{array}$ & $\begin{array}{l}582 \\
463 \\
386 \\
374\end{array}$ & $\begin{array}{l}\text { A: MMC (md) } \\
\text { B: MMC (md) + FT } \\
\text { A: MMC (hd) } \\
\text { B: MMC (hd) + FT }\end{array}$ & $\begin{array}{l}46.7 / 5 \\
47.3 / 5 \\
54.6 / 5 \\
56.1 / 5\end{array}$ & $\begin{array}{l}\text { NS } \\
\text { NS }\end{array}$ & $\begin{array}{l}\text { Stage III } \\
\qquad \mathrm{A}<\mathrm{B} ; P<0.05\end{array}$ \\
\hline $\begin{array}{l}\text { Hattori [22] } \\
\quad(1986)\end{array}$ & $\begin{array}{l}925 \\
965 \\
983\end{array}$ & $\begin{array}{l}\text { A: MMC } \\
\text { B: MMC + FT } \\
\text { C: FT }\end{array}$ & $\begin{array}{l}52.1 / 5 \\
54.1 / 5 \\
53.4 / 5\end{array}$ & NS & $\begin{array}{l}\text { Stage III } \\
\qquad \begin{array}{l}\mathrm{A}<\mathrm{B} ; P<0.001 \\
\mathrm{~A}<\mathrm{C} ; P<0.02\end{array}\end{array}$ \\
\hline $\begin{array}{l}\text { Nakazato [23] } \\
\quad(1986)\end{array}$ & $\begin{array}{l}81 \\
90\end{array}$ & $\begin{array}{l}\text { A: MMC + 5-FU } \\
\text { B: MMC + HCFU }\end{array}$ & - & NS & $\mathrm{n}(+) \operatorname{ps}(+) \mathrm{A}<\mathrm{B}$ \\
\hline $\begin{array}{l}\text { Maehara [24] } \\
\quad(1990)\end{array}$ & $\begin{array}{l}24 \\
22\end{array}$ & $\begin{array}{l}\text { A: MMC + FT } \\
\text { B: MMC + UFT }\end{array}$ & $\begin{array}{l}13 / 5 \\
23 / 5\end{array}$ & 0.045 & \\
\hline $\begin{array}{l}\text { Kubota [25] } \\
\quad(1994)\end{array}$ & $\begin{array}{l}163 \\
162\end{array}$ & $\begin{array}{l}\mathrm{A}: \mathrm{MMC}+\mathrm{FT} \\
\mathrm{B}: \mathrm{MMC}+\mathrm{FT}+\mathrm{MMC}\end{array}$ & - & NS & $\begin{array}{l}\text { Curative } \\
\qquad \mathrm{A}<\mathrm{B} ; P<0.05\end{array}$ \\
\hline $\begin{array}{l}\text { Arima [26] } \\
\quad(1994)\end{array}$ & $\begin{array}{l}117 \\
113\end{array}$ & $\begin{array}{l}\text { A: MMC + FT } \\
\text { B: MMC + UFT }\end{array}$ & $\begin{array}{l}39 / 5 \\
55 / 5\end{array}$ & NS & $\begin{array}{l}\text { Curative } \\
\qquad \mathrm{A}<\mathrm{B} ; P<0.05\end{array}$ \\
\hline $\begin{array}{l}\text { Nakajima [27] } \\
\text { (1994) }\end{array}$ & $\begin{array}{l}155 \\
155 \\
156\end{array}$ & $\begin{array}{l}\text { A: MMC/5-FU/Ara C + 5-FU } \\
\text { B: MMC/5-FU/Ara C + UFT } \\
\text { C: MMC/5-FU + UFT }\end{array}$ & $\begin{array}{l}70.8 / 5 \\
66.7 / 5 \\
62.5 / 5\end{array}$ & NS & \\
\hline $\begin{array}{l}\text { Danno [28] } \\
\quad(2001)\end{array}$ & $\begin{array}{l}707 \\
703\end{array}$ & $\begin{array}{l}\text { A: MMC (hd) + UFT (hd) } \\
\text { B: MMC (ld) + UFT (ld) }\end{array}$ & $\begin{array}{l}57.9 / 5 \\
53.7 / 5\end{array}$ & NS & $\mathrm{n}(+) \operatorname{ps}(-) \mathrm{A}>\mathrm{B}$ \\
\hline
\end{tabular}

NS, Not significant; HCFU, carmofur; md, moderate close; hd, high dose; ld, low dose; n, node; ps, serosal invasion 
+ FT, which was considered an encouraging finding. Arima et al. [26] also examined the clinical efficacy of MMC + UFT vs MMC + FT in resected gastric cancer and found similar results. Danno et al. [28] recently reported the results of a large randomized control trial investigating the correlation between efficacy and dose intensity of postoperative adjuvant chemotherapy with MMC and UFT. A total of 1410 patients were allocated to a low-dose group (MMC, $8 \mathrm{mg} / \mathrm{m}^{2}$ on the day of surgery and UFT, $300 \mathrm{mg} /$ day for 6 months) and a highdose group (MMC, $8 \mathrm{mg} / \mathrm{m}^{2}$ on the day of surgery and at 4, 10, 16, 22 weeks after surgery and UFT, $600 \mathrm{mg} /$ day for 6 months). The disease-free survival rate of the patients in the high-dose group was significantly higher than that of those in the low-dose group, although the differences in overall survival rates were not significant. The survival rates of patients with positive nodes without serosal invasion: $\mathrm{n}(+)$ and $\mathrm{ps}(-)$, were significantly higher in the high-dose group than in the low-dose group. These reports suggest that adjuvant chemotherapy with fluoropyrimidines should be carefully designed to achieve an effective dose intensity of 5-FU in the blood.

\section{Chemoimmunotherapy}

The results of adjuvant chemoimmunotherapy trials in Japan reported since 1984 are summarized in Table 3
[29-37]. Immunostimulators, such as PSK and OK-432, have been widely used in Japan during the past two decades. In an early study reported in 1984, Fujimoto et al. [29] and Niimoto et al. [30] evaluated the effectiveness of schizophillan or levamisole, respectively, in addition to MMC plus FT. They found no significant survival advantage for chemoimmunotherapy, except for stage III patients. Koyama et al. [31] published the results of a randomized clinical study comparing FT and FT plus Nocardia rubra cell wall skeleton. In that study, the survival rate was significantly higher in the chemoimmunotherapy group. Niimoto et al. [32] investigated the effect of PSK with adjuvant chemotherapy for gastric cancer. PSK, a protein-bound polysaccharide ( $\beta$-D glucan) extracted from the mycelia of Criolus versicolor of the Basidiomycetes, is known to induce interleukin (IL)-1, IL-6, and IL-8, as well as tumor necrosis factor and macrophage chemotactic factor. A total of 579 patients were randomized to either MMC + PSK, MMC + FT, or MMC + FT + PSK groups. The difference in 5-year survival rates among the three arms was significant. We also observed a survival advantage at 15 years in treated patients who received MMC + FT + PSK [18]. In particular, adjuvant chemoimmunotherapy was effective in patients with $\mathrm{ps}(+) / \mathrm{n}(-)$ or ps(-)/n(+). In 1994, Nakazato et al. [35] published the final results of a randomized control trial performed to examine the efficacy of PSK in gastric cancer when com-

Table 3. Adjuvant chemoimmunotherapy for gastric cancer in Japan

\begin{tabular}{|c|c|c|c|c|c|}
\hline $\begin{array}{l}\text { Author } \\
\text { (year) }\end{array}$ & $\begin{array}{l}\text { No. of } \\
\text { patients }\end{array}$ & Treatment & Percent survival/years & $P$ value & $\begin{array}{l}\text { Suggested } \\
\text { data }\end{array}$ \\
\hline $\begin{array}{l}\text { Fujimoto [29] } \\
\quad(1984)\end{array}$ & $\begin{array}{l}169 \\
157\end{array}$ & $\begin{array}{l}\mathrm{A}: \mathrm{MMC}+\mathrm{FT} \\
\mathrm{B}: \mathrm{MMC}+\mathrm{FT}+\text { schizophyllan }\end{array}$ & $\begin{array}{l}55 / 3 \\
55 / 3\end{array}$ & NS & $\begin{array}{l}\text { Stage III } \\
\qquad \mathrm{A}<\mathrm{B} ; P=0.08\end{array}$ \\
\hline $\begin{array}{l}\text { Niimoto [30] } \\
\quad(1984)\end{array}$ & $\begin{array}{l}77 \\
78\end{array}$ & $\begin{array}{l}\mathrm{A}: \mathrm{MMC}+\mathrm{FT} \\
\mathrm{B}: \mathrm{MMC}+\mathrm{FT}+\mathrm{LV}\end{array}$ & $\begin{array}{l}75 / 2 \\
80 / 2\end{array}$ & NS & $\begin{array}{l}\text { Stage III } \\
\qquad \mathrm{A}<\mathrm{B} ; P<0.01\end{array}$ \\
\hline $\begin{array}{l}\text { Koyama }[31] \\
\quad(1986)\end{array}$ & $\begin{array}{r}98 \\
115\end{array}$ & $\begin{array}{l}\text { A: FT } \\
\text { B: FT + N-CWS }\end{array}$ & $\begin{array}{l}60.2 / 5 \\
73.2 / 5\end{array}$ & $<0.05$ & \\
\hline $\begin{array}{l}\text { Niimoto }[32] \\
\quad(1988)\end{array}$ & $\begin{array}{l}189 \\
199 \\
191\end{array}$ & $\begin{array}{l}\text { A: MMC + PSK } \\
\text { B: MMC + FT } \\
\text { C: MMC + FT + PSK }\end{array}$ & $\begin{array}{l}64.1 / 5 \\
58.5 / 5 \\
71.5 / 5\end{array}$ & $<0.05$ & \\
\hline $\begin{array}{l}\text { Hattori [33] } \\
\quad(1990)\end{array}$ & $\begin{array}{l}1357 \\
1426 \\
1363 \\
1338\end{array}$ & $\begin{array}{l}\text { A: MMC + FT } \\
\text { B: MMC + FT + PSK } \\
\text { C: MMC + FT + PCB } \\
\text { D: MMC + FT }\end{array}$ & $\begin{array}{l}62.6 / 3 \\
71.6 / 3 \\
68.7 / 3 \\
69.1 / 3\end{array}$ & NS & \\
\hline $\begin{array}{l}\text { Maehara [18] } \\
\quad(1990)\end{array}$ & $\begin{array}{l}137 \\
118\end{array}$ & $\begin{array}{l}\text { A: } \mathrm{MMC}+\mathrm{FT}+\mathrm{PSK} \\
\mathrm{B}: \text { Control }\end{array}$ & $\begin{array}{l}56.9 / 15 \\
47.5 / 15\end{array}$ & $<0.035$ & \\
\hline $\begin{array}{l}\text { Niimoto [34] } \\
\quad(1990)\end{array}$ & $\begin{array}{l}45 \\
51\end{array}$ & $\begin{array}{l}\text { A: } \mathrm{MMC}+\mathrm{FT} \\
\mathrm{B}: \mathrm{MMC}+\mathrm{FT}+\text { Bestatin }\end{array}$ & $\begin{array}{l}37.6 / 7 \\
56.5 / 7\end{array}$ & NS & $\begin{array}{l}\mathrm{ps}(+) \mathrm{A}<\mathrm{B} \\
\quad P<0.05\end{array}$ \\
\hline $\begin{array}{l}\text { Nakazato [35] } \\
\quad(1994)\end{array}$ & $\begin{array}{l}129 \\
124\end{array}$ & $\begin{array}{l}\text { A: MMC + 5-FU } \\
\mathrm{B}: \mathrm{MMC}+5-\mathrm{FU}+\mathrm{PSK}\end{array}$ & $\begin{array}{l}60 / 5 \\
73 / 5\end{array}$ & $P=0.044$ & \\
\hline $\begin{array}{l}\text { Sugimachi [36] } \\
\quad(1997)\end{array}$ & $\begin{array}{r}100 \\
96\end{array}$ & $\begin{array}{l}\text { A: MMC + UFT (md) + PSK } \\
\text { B: MMC + UFT (hd) + PSK }\end{array}$ & $\begin{array}{l}58.6 / 5 \\
69.4 / 5\end{array}$ & $<0.05$ & \\
\hline
\end{tabular}

NS, Not significant; LV, Leucovorin; N-CWS, Nocardia rubra; PCB, picibanil (OK-432) 
bined with postoperative adjuvant chemotherapy of $\mathrm{MMC}+5 \mathrm{FU}$. This trial was carefully designed, focusing on the category of patients with positive purified protein derivative of tuberculin (PPD) skin test, T2 or T3 tumors, and pathologically proven curative surgery. The overall 5-year survival rates were $73.0 \%$ for the PSK arm and $60.0 \%$ for the control arm, with a significant difference. We recently demonstrated the impact of dose intensity of UFT combined with MMC + PSK on the survival of patients with curative surgery [36]. Patients prescribed higher doses of UFT survived for significantly longer, with a lower peritoneal recurrence rate. This result demonstrated that dose intensity is crucial in adjuvant chemotherapy for patients with gastric cancer for achieving a decrease in the recurrence rate and an improvement in the survival rate.

\section{Western postoperative adjuvant chemotherapy trials}

The results of Western studies published since 1980 are summarized in Table 4 [37-52]. There were few studies that demonstrated survival benefits of postoperative adjuvant chemotherapy over surgery alone. The 5-year survival rates for surgery alone ranged from $20 \%$ to $40 \%$. In these patients, it is questionable whether or not curative surgery had been conducted, and it seems to be difficult to achieve positive results with postoperative adjuvant chemotherapy in these patients with a poor prognosis. In 1983, Alcobendas et al. [39] reported on a trial that compared treatment with MMC to observation alone after surgery. Although there was a significant survival advantage for treatment with MMC, the number of patients was very small and the follow-up

Table 4. Adjuvant chemotherapy for gastric cancer: Western trials

\begin{tabular}{|c|c|c|c|c|c|}
\hline $\begin{array}{l}\text { Author } \\
\text { (year) }\end{array}$ & $\begin{array}{l}\text { No. of } \\
\text { patients }\end{array}$ & Treatment & Percent survival/years & $P$ value & $\begin{array}{l}\text { Suggested } \\
\text { data }\end{array}$ \\
\hline $\begin{array}{l}\text { Hugier [37] } \\
\quad(1980)\end{array}$ & $\begin{array}{l}27 \\
26\end{array}$ & $\begin{array}{l}\text { A: 5-FU/VBL/CPA } \\
\text { B: Control }\end{array}$ & $\begin{array}{l}18 / 5 \\
18 / 5\end{array}$ & NS & \\
\hline $\begin{array}{l}\text { Douglass [38] } \\
\text { (1982) }\end{array}$ & $\begin{array}{l}71 \\
71\end{array}$ & $\begin{array}{l}\text { A: } 5-\mathrm{FU} / \mathrm{Me}-\mathrm{CCNU} \\
\text { B: Control }\end{array}$ & $\begin{array}{l}45 / 5 \\
32 / 5\end{array}$ & $P=0.06$ & \\
\hline $\begin{array}{l}\text { Alcobendas [39] } \\
\text { (1983) }\end{array}$ & $\begin{array}{l}33 \\
37\end{array}$ & $\begin{array}{l}\text { A: MMC } \\
\text { B: Control }\end{array}$ & $\begin{array}{l}79 / 5 \\
38 / 5\end{array}$ & $P<0.001$ & \\
\hline $\begin{array}{l}\text { Higgins [40] } \\
\quad(1983)\end{array}$ & $\begin{array}{l}156 \\
156\end{array}$ & $\begin{array}{l}\text { A: } 5-\mathrm{FU} / \mathrm{Me}-\mathrm{CCNU} \\
\text { B: Control }\end{array}$ & $\begin{array}{l}38 / 5 \\
39 / 5\end{array}$ & NS & \\
\hline $\begin{array}{l}\text { Engstrom [41] } \\
\text { (1985) }\end{array}$ & $\begin{array}{l}91 \\
89\end{array}$ & $\begin{array}{l}\text { A: } 5-\mathrm{FU} / \mathrm{Me}-\mathrm{CCNU} \\
\text { B: Control }\end{array}$ & $\begin{array}{l}57 / 2 \\
57 / 2\end{array}$ & NS & \\
\hline $\begin{array}{l}\text { Schlag [42] } \\
\quad(1987)\end{array}$ & $\begin{array}{l}42 \\
53\end{array}$ & $\begin{array}{l}\text { A: 5-FU/BCNU } \\
\text { B: Control }\end{array}$ & $\begin{array}{l}57 / 5 \\
43 / 5\end{array}$ & NS & \\
\hline $\begin{array}{l}\text { Allum [43] } \\
\text { (1989) }\end{array}$ & $\begin{array}{l}141 \\
140 \\
130\end{array}$ & $\begin{array}{l}\text { A: MMC/5-FU } \\
\text { B: MMC/5-FU/CMFV } \\
\text { C: Control }\end{array}$ & $\begin{array}{l}11 / 5 \\
17 / 5 \\
12 / 5\end{array}$ & NS & \\
\hline $\begin{array}{l}\text { Coombes [44] } \\
\text { (1990) }\end{array}$ & $\begin{array}{l}133 \\
148\end{array}$ & $\begin{array}{l}\text { A: FAM } \\
\text { B: Control }\end{array}$ & $\begin{array}{l}45 / 5 \\
35 / 5\end{array}$ & NS & $\mathrm{T} 3,4 \mathrm{~A}>\mathrm{B}(P=0.04)$ \\
\hline $\begin{array}{l}\text { Krook [45] } \\
\quad(1991)\end{array}$ & $\begin{array}{l}61 \\
64\end{array}$ & $\begin{array}{l}\text { A: 5-FU/ADM } \\
\text { B: Control }\end{array}$ & $\begin{array}{l}32 / 5 \\
33 / 5\end{array}$ & NS & \\
\hline $\begin{array}{l}\text { Grau [46] } \\
\quad(1993)\end{array}$ & $\begin{array}{l}68 \\
66\end{array}$ & $\begin{array}{l}\text { A: MMC } \\
\text { B: Control }\end{array}$ & $\begin{array}{l}41 / 5 \\
26 / 5\end{array}$ & $<0.025$ & \\
\hline $\begin{array}{l}\text { MacDonald [47] } \\
\text { (1995) }\end{array}$ & $\begin{array}{r}93 \\
100\end{array}$ & $\begin{array}{l}\text { A: FAM } \\
\text { B: Control }\end{array}$ & $\begin{array}{l}37 / 5 \\
32 / 5\end{array}$ & NS & \\
\hline $\begin{array}{l}\text { Lise [48] } \\
(1995)\end{array}$ & $\begin{array}{l}155 \\
159\end{array}$ & $\begin{array}{l}\text { A: FAM } \\
\text { B: Control }\end{array}$ & $\begin{array}{l}43 / 5 \\
40 / 5\end{array}$ & NS & \\
\hline $\begin{array}{l}\text { Neri [49] } \\
\quad(1996)\end{array}$ & $\begin{array}{l}48 \\
55\end{array}$ & $\begin{array}{l}\text { A: } 5-\mathrm{FU} / \mathrm{Epi} / \mathrm{FA} \\
\text { B: Control }\end{array}$ & $\begin{array}{l}13 / 3 \\
25 / 3\end{array}$ & $<0.01$ & \\
\hline $\begin{array}{l}\text { Tsavaris [50] } \\
(1996)\end{array}$ & $\begin{array}{l}42 \\
42\end{array}$ & $\begin{array}{l}\text { A: FEM } \\
\text { B: Control }\end{array}$ & - & NS & \\
\hline $\begin{array}{l}\text { Grau [51] } \\
(1998)\end{array}$ & $\begin{array}{l}45 \\
40\end{array}$ & $\begin{array}{l}\text { A: MMC } \\
\text { B: } M M C+F T\end{array}$ & $\begin{array}{l}44 / 5 \\
67 / 5\end{array}$ & $P=0.04$ & \\
\hline $\begin{array}{l}\text { Cirera [52] } \\
(1999)\end{array}$ & $\begin{array}{l}76 \\
72\end{array}$ & $\begin{array}{l}\text { A: MMC + FT } \\
\text { B: Control }\end{array}$ & $\begin{array}{l}56 / 5 \\
36 / 5\end{array}$ & $P=0.04$ & \\
\hline
\end{tabular}

NS, Not significant; VBL, vinblastine; CPA, cyclophosphamide; Me-CCNU, smustine; BCNU, carmustine; CMFV, cyclophosphamide, methotrexate, 5FU, vincristine; FAM, 5FU + ADM + MMC; ADM, doxorubicin; Epi, epirubicin; FA, folinic acid; FEM, 5FU + Epi + MMC 
was too short to allow for definitive conclusions. In 1993 , Grau et al. [46] reported on 134 patients randomized to receive either MMC or no treatment after gastrectomy. In accordance with the earlier study, survival was significantly better in the MMC group compared with the nontreatment group. Grau et al. [51] reported their results for 85 patients who were randomized to receive either MMC plus FT or MMC alone. An improved 5year survival rate was demonstrated for the MMC plus FT group. Coombes et al. [44] studied the effect of 5-FU, Adriamycin, and MMC (FAM) in a prospective randomized adjuvant trial of 281 patients with curative resection who were allocated to FAM treatment or no treatment. Although there was no significant difference in disease-free or overall survival, subgroup analysis revealed better survival rates for the T3-T4 treated patients. In another adjuvant chemotherapy trial, reported by Neri et al. [49], 103 node-positive patients who underwent curative gastric resection were randomized to either observation or to administration of combination chemotherapy with epirubicin, 5-FU, and folinic acid for 7 months; a survival advantage was found for patients receiving the chemotherapy. Cirera et al. [52] reported significantly better overall and disease-free survivals in a group of resected stage III gastric cancer patients who were treated with MMC $20 \mathrm{mg} / \mathrm{m}^{2}$ and oral FT $400 \mathrm{mg}$ daily for 3 months when compared with surgery alone. These studies suggested the potential benefits of adjuvant chemotherapy for resected gastric cancer.

\section{Meta-analysis}

In general, meta-analysis is a way of providing the highest level of statistical evidence among pooled data derived from several clinical trials, and is, thus, most reliable.

In 1993, Hermans and colleagues [53] published the results of a meta-analysis of 11 randomized trials reported between 1980 and 1991, in which postoperative adjuvant chemotherapy for gastric cancer was compared with surgery alone. As a result of the analysis, they found no definitive improvement in the survival of patients who received postoperative adjuvant chemotherapy (odds ratio, $0.88 ; 95 \%$ confidence interval [CI], 0.78-1.08). Pignon et al. [54] criticized the results of this meta-analysis for its choice of trials. In response, Hermans and Bonenkamp [55] published an update of their analysis, with the odds ratio (OR) being significant (OR, 0.82; 95\% CI, 0.68-0.97) in 1994. Nakajima et al. [56] suggested a significant survival benefit for MMCbased adjuvant chemotherapy compared with surgery alone as a result of the meta-analysis of six randomized trials that included 1177 gastric cancer patients who underwent curative surgery (OR, 0.63; 95\% CI, 0.510.79). Recently, Earle and Maroun [57] evaluated the effect of adjuvant chemotherapy in gastric cancer by the meta-analysis of 13 randomized control trials performed in non-Asian countries. They found a significant survival benefit for patients with adjuvant chemotherapy over patients with surgery alone, with an OR of 0.80 (95\% CI, 0.66-0.97). Subgroup analyses indicated a trend towards a larger magnitude of the effect when analysis was restricted to trials in which at least twothirds of the patients had node-positive disease. Mari et al. [58] presented the results of a meta-analysis of 20 randomized trials with a surgery-alone control arm. They also demonstrated the survival impact of adjuvant chemotherapy on curative surgery for gastric cancer, with an OR of 0.82 (95\% CI, 0.75-0.89). They suggested a trend of favorable results in 5-FU-based regimens, and of unfavorable results in adriamycin-including regimens.

These meta-analysis results suggest that a possible survival advantage of adjuvant chemotherapy after curative surgery for gastric cancer may be proven by a well designed clinical trial comparing adjuvant chemotherapy with observation alone following curative surgery, in which a sufficient number of patients is enrolled and effective chemotherapeutic regimens with sufficient dose intensity are employed.

\section{Ongoing studies and future prospects}

In general, with the systemic treatment regimens available in the past, no major decrease in recurrence rates has been shown. The efficacy of treatment with routine postoperative systemic chemotherapy remains unproved. Several new approaches are currently undergoing intensive studies.

Early Japanese trials enrolled patients at all stages of disease and yielded inadequate samples, which may account for the nonsignificant results. Early-stage gastric cancer could be cured by surgery alone. By contrast, late stage cancer resulted in an excessive residual tumor burden, even after surgery. Subset analyses of past trials indicated that adjuvant chemotherapy may show a survival advantage for moderately locally advanced gastric cancer, such as stages II or III. Thus, early- or late-stage gastric cancers might be excluded from clinical trials in an adjuvant setting. The National Surgical Adjuvant Study (NSAS)-gastric cancer (GC) trial was designed, based on subset analysis of the results of Nakajima et al. [20], which contained the agent UFT [59]. In the NSASGC trial, patients with pathologically proven curative surgery for gastric cancer with negative serosal invasion (t2) and positive nodes ( $\mathrm{n} 1$ or $\mathrm{n} 2$ ) are divided into two groups: UFT treatment $\left(360 \mathrm{mg} / \mathrm{m}^{2}\right.$ for 16 months) and surgery alone, and the survival and toxicity profiles of the groups will be compared.

Chemotherapy plus concurrent radiation has recently attracted much attention in the United States. An inter- 
group 116 trial was conducted to test the hypothesis that postoperative chemoradiation therapy would decrease the risk of recurrence and, thereby, increase the cure rate for patients with resected gastric cancer [60]. This trial included 556 patients with stages Ib-IV gastric cancer, who were divided into 275 patients receiving surgery alone (control) and 281 patients treated with 5-FU plus leucovorin (LV) and irradiation (4500cGy) [61]. A significant prolongation of the median survival was noted, with 35 months for the treatment group and 28 months for the control. Analysis of the failure pattern in the study suggested that adjuvant chemoradiation suppressed locoregional relapse. These results indicated that 5 -FU $+\mathrm{LV}+$ radiation is a candidate for a standard adjuvant treatment regimen for locally advanced gastric cancer, but lymph node dissection was inadequate for enrolled patients with D1 of $36 \%$ and D2 of $10 \%$. Surgical treatment with D2 dissection could decrease the need for radiation.

One of the new approaches taken in an attempt to improve the survival of patients undergoing curative gastrectomy is the use of preoperative (neoadjuvant) systemic chemotherapy. The goal of these treatment plans is to allow an early attack on systemic micrometastatic disease and, by downstaging the primary tumor, to increase the percentage of patients who are able to undergo curative resection. A number of phase II trials have been performed to investigate the potential of preoperative chemotherapy to influence the outcome for patients with gastric cancer [62-64]. A positive impact on prognosis was claimed. Lowy et al. [65] analyzed three phase II studies and showed response rates of $24 \%-38 \%$ and a rate of curative resection of $73 \%$. With multivariate analyses, they demonstrated that the effect of neoadjuvant chemotherapy was the only prognostic factor. Recently, a small-scale phase III trial was reported by Kang et al. [66], using neoadjuvant chemotherapy followed by surgery vs surgery alone for locally advanced gastric cancer. While the curative resection rate was significantly higher and the postoperative stage was significantly lower for the neoadjuvant group, there was no significant difference in overall survival. Thus, this approach, although promising, requires definitive random phase III trials with a higher statistical power before a firm conclusion can be reached. Preoperative chemoradiation using continuous 5 -FU $\left(300 \mathrm{mg} / \mathrm{m}^{2}\right)$ with $45 \mathrm{~Gy}$ for potentially resectable gastric cancer has been conducted in an attempt to improve locoregional control and overall survival [67]. Preliminary results showed an overall median survival of 34 months and disease-specific survival greater than $60 \%$ at 4 years, with a high rate of tumor downstaging, and without significant preoperative toxicity.

Another approach is the delivery of chemotherapy directly to the peritoneal space [9]. The rationale for the use of this administration route is based on the finding that more than half of the recurrence sites after curative surgery are in the peritoneal space. The rates of peritoneal recurrence in both treatment and control arms have seemed to be similar in adjuvant intravenous therapy studies. The pharmacokinetic advantages of intraperitoneal (IP) chemotherapy have been well described. Drug concentrations within the peritoneal cavity are from severalfold to one to two logs higher than the concentrations that can be achieved by oral or intravenous administration. IP chemotherapy has also been shown to be capable of treating both peritoneal and liver micrometastasis in a rat model [68]. In the clinical setting, Hagiwara et al. [69] reported a significant improvement in 3-year survival (69\% vs $27 \%$, surgery alone) in patients treated with IP administration of carbon-absorbed MMC at surgery. An Austrian randomized multicenter trial, however, could not determine any improvement in survival, and found an increased rate of postoperative complications with the same drug [70]. Schiessel et al. [71] and Sautner et al. [72] performed IP cisplatin treatment and concluded that IP cisplatin had no significant impact on recurrence. More recently, Sugarbaker and Yonemura [73] reviewed the clinical results of several IP studies reported for gastric cancer with peritoneal seeding. Although not all those treated were in an adjuvant setting, these investigators stressed the value of an aggressive surgical approach, including gastrectomy with peritonectomy, to eliminate all visible implants, combined with perioperative IP chemotherapy, for selected patients.

Future trials may evaluate the use of recently developed new cytotoxic agents, such as TS-1 [74-76], irinotecan [77], paclitaxel [78], and docetaxel, [80] either alone or in combination (Fig. 1). Among these, the oral 5-FU prodrug, TS-1, FT-gimestat-otastat potassium, has shown significant activity in the treatment of advanced gastric cancer, with response rates of $49 \%$. In addition, the response rate to TS- 1 is further enhanced, to more than $70 \%$, by combination with cisplatin [80]. This drug has been developed to increase the antitumor effect by inhibiting dihydropyrimidine dehydrogenase (DPD) activity, with gimestat, and also to decrease the

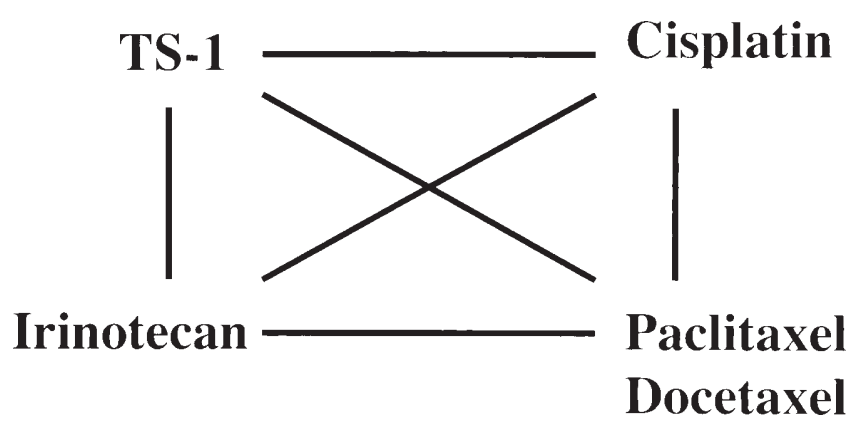

Fig. 1. Possible combinations of anticancer drugs for adjuvant chemotherapy 
adverse effect by protecting the gastrointestinal tract, with otastat potassium, thus resulting in a pharmacokinetic profile similar to that of continuous venous 5-FU infusion and with less toxicity and improved patient quality of life [81]. A recent report demonstrated both survival and toxicity advantages for continuous infusion over bolus infusion of 5-FU [82]. Because orally administered agents have pharmacokinetics that approximate those of continuous infusion without the patient inconvenience and morbidity associated with indwelling catheters and infusion pumps, oral preparations of fluoropyrimidines have several advantages when employed in an adjuvant setting and are now attracting considerable attention from oncologists worldwide [81]. Several clinical trials of adjuvant chemotherapy using such oral fluoropyrimidines in Japan have so far failed, however, to show a firm survival advantage for gastric cancer. This could be attributable to the low-dose intensity of the chemotherapy. Danno et al. [28] and Sugimachi et al. [37] demonstrated significant survival advantages by giving higher doses of UFT $(600 \mathrm{mg} /$ day $)$ compared with lower doses of UFT (300-400 mg/day), although the hematological and/or gastrointestinal toxicities increased in the higher-dose of UFT group. In patients with advanced colorectal cancer, a clear relationship between the 5-FU plasma level and efficacy has been noted [83]. With appropriate doses of fluoropyrimidines, an effective 5-FU plasma level, resulting in improved patient survival, can be achieved. Because TS-1 has a more nearly ideal profile with regard to both the increase of antitumor effects and the decrease of adverse effects compared with UFT, TS- 1 could be a potential candidate for future adjuvant chemotherapy for gastric cancer. A pilot study of TS- 1 in an adjuvant setting is now underway to evaluate the feasibility of this drug as an adjuvant chemotherapeutic agent.

Irinotecan, an inhibitor of DNA to topoisomerase $\mathrm{I}$, is also a unique and attractive agent, developed in Japan, and it has been investigated in combination with cisplatin. Boku et al. [84] reported that the response rate of patients treated with irinotecan and cisplatin without prior chemotherapy was $59 \%$, with a median survival time of 11 months. Severe side effects of the combination were also noted, so that the feasibility of the use of this combination chemotherapy as an adjuvant treatment must be evaluated in future trials. Paclitaxel and docetaxel, novel taxoids which act as mitotic spindle poisons and induce a mitotic block, have potent antineoplastic activities. These taxoids, when combined with cisplatin and/or 5-FU, showed response rates of more than $50 \%$, and could be attractive tools in an adjuvant setting for gastric cancer $[85,86]$.

To date, no definitive conclusion has yet been drawn from randomized clinical trials of adjuvant chemo- therapy for gastric cancer, because few studies have shown a significant positive impact on survival as compared with surgery alone. The negative results of most previous clinical studies do not necessarily mean that the adjuvant chemotherapy approach to gastric cancer treatment is not working. The positive data from metaanalyses may suggest potential survival advantages of adjuvant chemotherapy, but these must be proven in future by well designed clinical trials comparing adjuvant chemotherapy vs surgery alone, in which sufficient numbers of patients are enrolled and effective chemotherapeutic regimens with appropriate dose intensity are employed.

Newly developed anticancer agents and/or newer therapeutic combinations or strategies (neoadjuvant chemotherapy, chemoradiotherapy, intraperitoneal chemotherapy) have the potential to benefit high-risk patients.

\section{References}

1. Korenaga D, Moriguchi S, Orita H, Kakeji Y, Haraguchi M, Maehara Y, et al. Trends in survival rates in Japanese patients with advanced carcinoma of the stomach. Surg Gynecol Obstet 1992;174:387-93.

2. Maehara Y, Emi Y, Baba H, Adachi Y, Akazawa K, Ichiyoshi Y, et al. Recurrences and related characteristics of gastric cancer. $\mathrm{Br}$ J Cancer 1996;74:975-9.

3. Shimada K, Ajani JA. Adjuvant therapy for gastric carcinoma patients in the past 15 years: a review of Western and oriental trials. Cancer 1999;86:1657-68.

4. De Vivo R, Pignata S, Palaia R, Parisi V, Daniele B. The role of chemotherapy in the management of gastric cancer. J Clin Gastroenterol 2000;30:364-71.

5. Douglass HO Jr. Adjuvant therapy of gastric cancer: have we made any progress? Ann Oncol 1994;5:S49-S57.

6. Bleiberg H, Gerard B, Deguiral P. Adjuvant therapy in resectable gastric cancer. Br J Cancer 1992;66:987-91.

7. Bonenkamp JJ, Hermans J, Sasako M, van de Velde CJH, for the Dutch Gastric Cancer Group. Extended lymph-node dissection for gastric cancer. New Engl J Med 1999;340:908-14.

8. Nakajima T. Review of adjuvant chemotherapy for gastric cancer. World J Surg 1995;19:570-4.

9. Kelsen DP. Adjuvant and neoadjuvant therapy for gastric cancer. Semin Oncol 1996;23:379-89.

10. Sasako M, Sano T, Katai H, Okajima K, Maruyama K. Overview of clinical trials on adjuvant chemotherapy for curatively resected gastric cancer. Jpn J Cancer Chemother 1994;21:384-94.

11. Kimura T, Koyama Y. Three prospective controlled studies: part 2 (in Japanese). Rinshogeka (J Clin Surg) 1981;36:185-95.

12. Imanaga $H$, Nakazato $H$. Results of surgery for gastric cancer and effect of adjuvant mitomycin $\mathrm{C}$ on cancer recurrence. World $\mathrm{J}$ Surg 1977;1:213-21.

13. Nakajima T, Fukami A, Ohashi I, Kajitani T. Long-term followup study of gastric cancer patients treated with surgery and adjuvant chemotherapy with mitomycin C. Int J Clin Pharmacol 1978;16:209-16.

14. Nakajima T, Fukami A, Takagi K, Kajitani T. Adjuvant chemotherapy with mitomycin $\mathrm{C}$, and with a multi-drug combination of mitomycin C, 5-fluorouracil and cytosine arabinoside after curative resection of gastric cancer. Jpn J Clin Oncol 1980;10:187-94.

15. Ochiai T, Sato H, Hayashi R, Asano T, Sato H, Yamamura Y. Postoperative adjuvant immunotherapy of gastric cancer with 
BCG-cell wall skeleton: 3- to 6-year follow-up of a randomized clinical trial. Cancer Immunol Immunother 1983;14:167-71.

16. Nakajima T, Takahashi T, Takagi K, Kuno K, Kajitani T. Comparison of 5-fluorouracil with ftorafur in adjuvant chemotherapies with combined inductive and maintenance therapies for gastric cancer. J Clin Oncol 1984;2:1366-71.

17. Yamamura Y, Nishimura M, Sakamoto J, Yasui K, Morimoto T, Kato T, et al. A randomized controlled trial of surgical adjuvant therapy with mitomycin C, 5-fluorouracil and OK-432 for patients suffering from gastric cancer. Jpn J Clin Oncol 1986;13:2134-40.

18. Maehara Y, Moriguchi S, Sakaguchi Y, Emi Y, Kohnoe S, Tsujitani $\mathrm{S}$, et al. Adjuvant chemotherapy enhances long-term survival of patients with advanced gastric cancer following curative resection. J Surg Oncol 1990;45:169-72.

19. Fujii M, Sakabe T, Wakabayashi K, Kochi M, Mochizuki F, Kasakura Y, et al. The optimal period for orally administered fluoropyrimidines as an adjuvant chemotherapy for gastric cancer. A pilot study using 5-FU tablets compared with surgery alone. 1994;21:1199-208.

20. Nakajima $T$, Nashimoto A, Kitamura $M$, Kito $T$, Iwanaga $T$, Okabayashi K, et al. Adjuvant mitomycin and fluorouracil followed by oral uracil plus tegafur in serosa-negative gastric cancer: a randomized trial. Lancet 1999;354:273-7.

21. Inokuchi K, Hattori T, Taguchi T, Abe O, Ogawa N. Postoperative adjuvant chemotherapy for gastric carcinoma. Analysis of data on 1805 patients followed for 5 years. Cancer 1984;53:2393-7.

22. Hattori T, Inokuchi K, Taguchi T, Abe O. Postoperative adjuvant chemotherapy for gastric cancer, the second report. Analysis of data on 2873 patients followed for 5 years. Jpn J Surg 1986;16:17580.

23. Nakazato H, Koike A, Ichihashi H. A randomized controlled trial comparing short-term MF chemotherapy with MF and long-term carmofur chemotherapy as an adjuvant to curative resection of stomach cancer (in Japanese). Gann no Rinsho (Jpn J Cancer Clin) 1986;32:159-64.

24. Maehara Y, Watanabe A, Kakeji Y, Baba H, Kohnoe S, Sugimachi K. Postgastrectomy prescription of mitomycin C and UFT for patients with stage IV gastric carcinoma. Am J Surg 1990;160:242-4.

25. Kubota T, Kumai K, Kitajima M, Fujisaki M, Yamada Y, Ushijima $\mathrm{Y}$, et al. Dose intensity of mitomycin $\mathrm{C}$ in adjuvant cancer chemotherapy for patients with gastric cancer. J Surg Oncol 1994;57:40-5.

26. Arima S, Ohsato K, Hisatsugu T, Shimura H. Multicentre randomized study of adjuvant chemotherapy with mitomycin C and tegafur-uracil in gastric cancer. Eur J Surg 1994;160:227-32.

27. Nakajima $T$, Okabayashi $K$, Nakazato $H$, Iwanaga $T$, Ota $K$, Kinoshita T, et al. Adjuvant chemotherapy with MFC-related regimens for patients with gastric cancer after curative gastrectomy. J Jpn Soc Cancer Ther 1994;29:654-62.

28. Danno M, Shiroto H, Kunii Y, Ishibiki K, Yamamura Y, Sakamoto Y, et al. Study on the intensity of MMC and UFT in postoperative adjuvant chemotherapy for gastric cancer. Study report of JFMTC Study No.10. Jpn J Cancer Chemother 2001;28:195-203.

29. Fujimoto S, Furue H, Kimura T, Kondo K, Orita K, Taguchi T, et al. Clinical evaluation of schizophyllan adjuvant immunochemotherapy for patients with resectable gastric cancer. A randomized controlled trial. Jpn J Surg 1984;14:286-92.

30. Niimoto M, Hattori T, Ito I, Tamada R, Inokuchi K, Orita K, et al. Levamisole in postoperative adjuvant immunochemotherapy for gastric cancer. A randomized controlled study of the MMC+ tegafur regimen with or without levamisole. Report 1. Cancer Immunol Immunother 1984;18:13-8.

31. Koyama S, Ozaki A, Iwasaki Y, Sakita T, Osuga T, Watanabe A, et al. Randomized controlled study of postoperative adjuvant immunochemotherapy with Nocardia rubra cell wall skeleton $(\mathrm{N}-$ CWS) and tegafur for gastric carcinoma. Cancer Immunol Immunother 1986;22:148-54.
32. Niimoto M, Hattori T, Tamada S, Sugimachi K, Inokuchi K, Ogawa N. Postoperative adjuvant immunochemotherapy with mitomycin C, fturafur and PSK for gastric cancer. An analysis of data on 579 patients followed for 5 years. Jpn J Surg 1988;18:6816.

33. Hattori T, Nakajima T, Nakazato H, Tanabe T, Kikuchi K, Abe $\mathrm{O}$, et al. Postoperative adjuvant immunochemotherapy with mitomycin C, tegafur, PSK and/or OK-432 for gastric cancer, with special reference to the change in stimulation index after gastrectomy. Jpn J Surg 1990;20:127-36.

34. Niimoto M, Saeki T, Toi M, Nishiyama M, Hirai T, Yanagawa E, et al. Prospective randomized controlled study on Bestatin in resectable gastric cancer. Third report. Jpn J Surg 1990;20:18691.

35. Nakazato H, Koike A, Saji S, Ogawa N, Sakamoto J, et al. Efficacy of immunochemotherapy as adjuvant treatment after curative resection of gastric cancer. Lancet 1994;343:1122-6.

36. Sugimachi K, Maehara Y, Ogawa M, Kakegawa T, Tomita M. Dose intensity of uracil and tegafur in postoperative chemotherapy for patients with poorly differentiated gastric cancer. Cancer Chemother Pharmacol 1997;40:233-8.

37. Huguier M, Destroyes JP, Baschet C, Le Henand F, Bernard PF. Gastric carcinoma treated by chemotherapy after resection. Am J Surg 1980;139:197-9.

38. The gastrointestinal tumor study group (Douglass HO, et al.). Controlled trial of adjuvant chemotherapy following curative resection for gastric cancer. Cancer 1982;49:1116-22.

39. Alcobendas F, Milla A, Estape J, Curto J, Pera C. Mitomycin C as an adjuvant in resected gastric cancer. Ann Surg 1983;198:13-17.

40. Higgins GA, Amadeo JH, Smith DA, Humphrey EW, Keehn RJ. Efficacy of prolonged intermittent therapy with combined 5-FU and methyl-CCNU following resection for gastric carcinoma. Cancer 1983;52:1105-12.

41. Engstrom PF, Lavin PT, Douglass HO Jr, Brunner KW. Postoperative adjuvant 5-fluorouracil plus methyl-CCNU therapy for gastric cancer patients. Eastern Cooperative Oncology Group study. Cancer 1985;55:1868-73.

42. Schlag P. Adjuvant chemotherapy in gastric cancer. World J Surg 1987;11:473-7.

43. Allum WH, Hallissey MT, Kelly KA. Adjuvant chemotherapy in operable gastric cancer. Five-year follow-up of First British Stomach Cancer Group Trial. Lancet 1989;1:571-4.

44. Coombes RC, Schein PS, Chilvers CE, Wils J, Beretta G, Bliss $\mathrm{JM}$, et al. A randomized trial comparing adjuvant fluorouracil, doxorubicin, and mitomycin with no treatment in operable gastric cancer. International Collaborative Cancer Group. J Clin Oncol 1990;8:1362-9.

45. Krook JE, O'Connell MJ, Wieand HS, Beart RW Jr, Leigh JE, Kugler JW, et al. A prospective, randomized evaluation of intensive-course 5-fluorouracil plus doxorubicin as surgical adjuvant chemotherapy for resectable gastric cancer. Cancer 1991;67:24548.

46. Grau JJ, Estape J, Alcobendas F, Pera C, Daniels M, Teres J. Positive results of adjuvant MMC in resectable gastric cancer: a randomized trial on 134 patients. Eur J Cancer 1993;29A:340-2.

47. MacDonald JS, Fleming TR, Peterson RF, Berenberg JL, Mcclure S, Chapman RA, et al. Adjuvant chemotherapy with 5FU, Adriamycin, and mitomycin-C (FAM) versus surgery alone for patients with locally advanced gastric adenocarcinoma: a Southwest Oncology Group study. Ann Surg Oncol 1995;2:48894.

48. Lise M, Nitti D, Marchet A, Sahmoud T, Duez N, Fornasiero A, et al. Prognostic factors in resectable gastric cancer: results of EORTC study no. 40813 on FAM adjuvant chemotherapy. Ann Surg Oncol 1995;2:495-501.

49. Neri B, De Leonardis V, Romano S, Andreoli F, Pernice LM, Bruno L, et al. Adjuvant chemotherapy after gastric resection in node-positive cancer patients: a multicenter randomized study. $\mathrm{Br}$ J Cancer 1996;73:549-52. 
50. Tsavaris N, Tentas K, Kosmidis P, Mylonakis N, Sakelaropoulos $\mathrm{N}$, Kosmas $\mathrm{C}$, et al. A randomized trial comparing adjuvant fluorouracil, epirubicin, and mitomycin with no treatment in operable gastric cancer. Chemotherapy 1996;42:220-6.

51. Grau JJ, Estape J, Fuster J, Filella X, Visa J, Teres J, et al. Randomized trial of adjuvant chemotherapy with mitomycin plus ftorafur versus mitomycin alone in resected locally advanced gastric cancer. J Clin Oncol 1998;16:1036-9.

52. Cirera L, Balil A, Batiste-Alentorn E, Tusquets I, Cardona T, Arcusa A, et al. Randomized clinical trial of adjuvant mitomycin plus tegafur in patients with resected stage III gastric caner. J Clin Oncol 1999;17:3810-5.

53. Hermans J, Bonenkamp JJ, Boon MC, Bunt AM, Ohyama S, Sasako M, et al. Adjuvant therapy after curative resection for gastric cancer: meta-analysis of randomized trials. J Clin Oncol 1993:11:1441-7.

54. Pignon JP, Ducreux M, Rougier P. Meta-analysis of adjuvant chemotherapy in gastric cancer: a critical reappraisal. J Clin Oncol 1994;12:877-8.

55. Hermans J, Bonenkamp H. In reply (letter). J Clin Oncol 1994;12:879-80.

56. Nakajima T, Ota K, Ishihara S, Oyama S, Nishi M, Hamashima N. Meta-analysis of ten postoperative adjuvant chemotherapies for gastric cancer in CIH. Jpn J Cancer Chemother 1994;21:1800-5.

57. Earle CC, Maroun JA. Adjuvant chemotherapy after curative resection for gastric cancer in non-Asian patients: revisiting a meta-analysis of randomized trials. Eur J Cancer 1999;35:1059-64.

58. Mari E, Floriani I, Tinazzi A, Buda A, Belfiglio M, Valentini M, et al. Efficacy of adjuvant chemotherapy after curative resection for gastric cancer: a meta-analysis of published randomised trials. Ann Oncol 2000;11:837-43.

59. Takiuchi H, Ajani JA. Uracil-tegafur in gastric carcinoma: a comprehensive review. J Clin Oncol 1998;16:2877-85.

60. Kelsen DP. Postoperative adjuvant chemoradiation therapy for patients with resected gastric cancer: Intergroup 116. J Clin Oncol 2000; $18: 32$ s- $4 \mathrm{~s}$

61. Macdonald LS, Smalley S, Benedetti J, Estes N, Haller DG, Ajani JA, et al. Postoperative combined radiation and chemotherapy improves disease-free survival (DFS) and overall survival (OS) in resected adenocarcinoma of the stomach and G.E. junction. Results of intergroup study INT-0116 (SWOG9008) (abstract). Proc Am Soc Clin Oncol 2000;19:1.

62. Ajani JA, Mayer RJ, Ota DM, Steele GD, Evans D, Roh M, et al. Preoperative and postoperative combination chemotherapy for potentially resectable gastric carcinoma. JNCI 1993;85:1839-44.

63. Rougier P, Mahjoubi M, Lasser P, Ducreux M, Oliveira J, Ychou $\mathrm{M}$, et al. Neoadjuvant chemotherapy in locally advanced gastric carcinoma: a phase II trial with combined continuous intravenous 5-fluorouracil and bolus cisplatinum. Eur J Cancer 1994;30A: 1269-75.

64. Kelsen D, Karpeh M, Schwartz G, Gerdes H, Lightdale C, Botet J, et al. Neoadjuvant therapy of high-risk gastric cancer: a phase II trial of preoperative FAMTX and postoperative intraperitoneal fluorouracil-cisplatin plus intravenous fluorouracil. J Clin Oncol 1996;14:1818-28

65. Lowy AM, Mansfield PF, Leach SD, Pazdur R, Dumas P, Ajani JA. Response to neoadjuvant chemotherapy best predicts survival after curative resection of gastric cancer. Ann Surg 1999;229:303-8.

66. Kang YK, Choi DW, Im YH, et al. A phase III randomized comparison of neoadjuvant chemotherapy followed by surgery versus surgery for locally advanced stomach cancer. Proc Am Soc Clin Oncol 1996;15:503.

67. Mansfield PF, Lowy AM, Feig BW, Janjan N, Pisters PW, Rich TA, et al. Preoperative chemoradiation for potentially resectable gastric cancer (abstract). Proc Am Soc Clin Oncol 2000;19:246.

68. Archer S, Gray B. Intraperitoneal 5-fluorouracil infusion for treatment of both peritoneal and liver micrometastasis. Surgery 1990;108:502-7.
69. Hagiwara A, Takahashi T, Kojima O, Sawaki K, Yamaguchi T, Yamane T, et al. Prophylaxis with carbon-absorbed mitomycin against peritoneal recurrence of gastric cancer. Lancet 1992;339: 629-31.

70. Rosen HR, Jatzko G, Repse S, Potrc S, Neudorfer H, Sandbichler $\mathrm{P}$, et al. Adjuvant intraperitoneal chemotherapy with carbonabsorbed mitomycin in patients with gastric cancer: results of a randomized multicenter trial of the Austrian Working Group for Surg Oncol. J Clin Oncol 1998;16:2733-8.

71. Schiessel R, Funovics J, Schick B, Bohmig HJ, Depisch D, Hofbauer F, et al. Adjuvant intraperitoneal cisplatin therapy in patients with operated gastric carcinoma: results of a randomized trial. Acta Med Austriaca 1989;16:68-9.

72. Sautner T, Hofbauer F, Depisch D, Schiessel R, Jakesz R. Adjuvant intraperitoneal cisplatin chemotherapy does not improve long-term survival after surgery for advanced gastric cancer. J Clin Oncol 1994;12:970-4.

73. Sugarbaker PH, Yonemura Y. Clinical pathway for the management of resectable gastric cancer with peritoneal seeding: best palliation with a ray of hope for cure. Oncology 2000;58:96-107.

74. Sakata Y, Ohtsu A, Horikoshi N, Sugimachi K, Mitachi Y, Taguchi T. Late phase II study of novel oral fluoropyrimidine anticancer drug S-1 (1M Tegafur- $0.4 \mathrm{M}$ gimestat-1 M otastat potassium) in advanced gastric cancer patients. Eur J Cancer 1998;34:1715-20.

75. Sugimachi K, Maehara Y, Horikoshi N, Shimada Y, Sakata Y, Mitachi Y, et al. An early phase II study of oral S-1, a newly developed 5-fluorouracil derivative for advanced and recurrent gastrointestinal cancers. Oncology 1999;57:202-10.

76. Koizumi W, Kurihara M, Nakano S, Hasegawa K, The S-1 gastrointestinal cancer study group. Phase II study of S-1, a novel oral derivative of 5- fluorouracil, in advanced gastric cancer. Oncology 2000;58:191-7.

77. Futatsuki K, Wakui A, Nakao I, Sakata Y, Kambe M, Shimada Y, et al. Late phase II study of irinotecan hydrochloride (CPT-11) in advanced gastric cancer. Jpn J Cancer Chemother 1994;21:10338 .

78. Cascinu S, Graziano F, Cardarelli N, Marcellini M, Giordani P, Menichetti ET, Caralano G. Phase II study of paclitaxel in pretreated advanced gastric cancer. Anti-Cancer Drugs 1998;9:30710.

79. Sulkes A, Smyth J, Sessa C, Dirix LY, Vermorken JB, Kaye S, et al. Docetaxel (Taxotere TM) in advanced gastric cancer: results of a phase II clinical trial. Br J Cancer 1994;70:380-3.

80. Ohtsu A, Boku N, Nagashima F, Koizumi W, Tanabe S, Saigenji $\mathrm{K}$, et al. A phase I/II study of S-1 plus cisplatin (CDDP) in patients (pts) with advanced gastric cancer (AGC). Proc Am Soc Clin Oncol 2001;20:165a.

81. Hirata K, Horikoshi N, Aiba K, Okazaki M, Denno R, Sasaki K, et al. Pharmacokinetic study of S-1, a novel oral fluorouracil antitumor drug. Clin Cancer Res 1999;5:2000-5.

82. The meta-analysis group in cancer. Efficacy of intravenous continuous infusion of fluorouracil compared with bolus administration in advanced colorectal cancer. J Clin Oncol 1998;16:301-8.

83. Gamelin EC, Danquechin-Dorval E, Dumesnil YF, Maillart PJ, Goudier MJ, Burtin PC, et al. Relationship between 5fluorouracil (5-FU) dose intensity and therapeutic response in patients with advanced colorectal cancer receiving infusional therapy containing 5-FU. Cancer 1996;77:441-51.

84. Boku N, Ohtsu A, Shimada Y, Shirao K, Seki S, Saito H, et al. Phase II study of a combination of irinotecan and cisplatin against metastatic gastric cancer. J Clin Oncol 1999;17:319-23.

85. Kim YH, Shin SW, Kim BS, Kim JG, Mok YJ, Kim CS, et al. Paclitaxel, 5-fluorouracil, and cisplatin combination chemotherapy for the treatment of advanced gastric carcinoma. Cancer 1999;85:295-301.

86. Roth AD, Maibach R, Martinelli G, Fazio N, Aapro MS, Pagani $\mathrm{O}$, et al. Docetaxel (Taxotere ${ }^{\odot}$ )-cisplatin (TC): an effective drug combination in gastric carcinoma. Ann Oncol 2000;11:301-6. 